\title{
P-541＼cjkstart尿中PSA測定における採尿方法ならびに日 内変動の検討
}

\author{
東京医科大学泌尿器科 1 ) \\ 秋山 昭人 1）伊藤 貴章1）山本 真也 ${ }^{1 ）}$ 続 真弘 ${ }^{1 ）}$ 金 泰正 ${ }^{1 ）}$ \\ 山本 豊1 ${ }^{1}$ 鮫島 剛1) 三木 誠1) \\ 【目的】我々は第87回の本総会において尿中PSAを用いた前立腺癌 \\ スクリーニングについて検討し,尿/血清PSA比が特にPSA gray-zone \\ 症例において診断特異性の点で有用である事を報告した。今回,尿 \\ 中のPSAのより正確かつ再現性のある測定について検討した。【対 \\ 象と方法】(1)採尿方法（2杯分尿の前尿と後尿の比較）検討：平 \\ 成11年4-6月に当科前立腺外来にて前立腺生検を受け、生検直前に \\ 前尿 $(50 \mathrm{ml})$,後尿 $(100 \mathrm{ml}$ 以上)の採取が可能であった 35 例。前尿,後尿 \\ 各々についてPSAを測定し,病理診断とともに検討。(2)尿中PSA日 \\ 内変動の検討：平成11年8 - 9月に前立腺癌もしくは肥大症治療目 \\ 的で当科に入院し,前立腺操作前に 1 日 5 点以上の検体採取が可能で \\ あった10例につき㭘討。【結果】(1)前尿,後尿の比較：前立腺肥大 \\ 症, 癌にかかわりなく尿中PSA值は前尿に比べ後尿でほほ半隇(前立 \\ 腺肥大症で52+/-24\%, 前立腺癌で53+/-27\%)し,後尿でPSAの上昇が見 \\ られたのは1例のみ(肥大症)でその差も䛊差範囲と考えられた。 \\ (1)日内変動については症例間で一定の傾向は見られず,変動係数 \\ (CV値)にもばらつきが見られた。しかし各症例内の值の変動の幅 \\ は許容範囲内と思われた。【考察】日内変動についてはより詳細 \\ な検討を要するが,(1)の結果から尿中PSAが腎排泄によるものとす \\ ることは否定的と思われた。
}

尿中PSA PSA 前立腺癌スクリーニング

\section{P-543 PSA值がグレーゾーン症例におけるMRIの 有效性の検討}

\begin{abstract}
国立東静病院 泌尿器科 1）日本医科大学 2 ) 国立東静病院 放射線科 3 )

桐山 功1）大場 修司1）木全亮二2）清水宏之 ${ }^{2 ）}$ 秋元成太 ${ }^{2)}$ 杉山彰3) 久保田 元 $^{3)}$ 奥原博久 ${ }^{3)}$

【目的】PSA值は前立腺癌の診断において最も鋭敏で有効であるが， グレーゾーンにおいては，その扱いが問題となる，そのような症 例におけるMRIの有効性を検討した.【対象と方法】対象は199 8 年 10 月から 1999 年 10 月の 1 年間に当院を受診した 50 歳以上の患者のうち, 直腸内指診や経直腸的超音波断層法で前立 腺癌が疑われたPSA值がグレーゾーン $(2.2 \sim 10.0 \mathrm{ng} / \mathrm{ml})$ の症例で, MRIを施行し, 且つ生検やTUR-Pで病理学的検査が実施された 30 例である，MRIは体幹コイルを用い，T1とT2強調像を撮影し検討 した.【結果】MRIで前立腺癌を疑った症例は, 前立腺辺縁領域の T 2 強調像が低信号の場合と前立腺内に限局する massが存在する 場合で11例に認められた。 そのうち病理学的に腺癌を認めた症例 は6例（54.5\%）であった。これに対し，MRIでnegative studyであ った19例のうち腺癌が認められた症例は 2 例 $(10.5 \%)$ のみであ った、【総括】PSA值がグレーゾーンで, さらに生検等の精査を進 めていくべきか否かを決めかねている場合に，MRI所見は有効な 判断材料となりうることが示唆された
\end{abstract}

前立腺癌 MRI PSA

\section{P-542 PSA軽度上界症例におけるMRIを用いた PSAD, PSATZの臨床的検尉}

\begin{abstract}
神奈川県立厚木病院 泌尿器科1）
東京慈恵会医科大学 泌尿器科2)

古田 昭 ${ }^{1 ）}$ 箈田 周…1）滝沢 明利1）岩室 紳也 ${ }^{1 ）}$ 鈴木 正泰1) 田代 和也 ${ }^{1 ）}$ 長谷川 倫男2）鈴木 直樹2）大石 幸彦2）

【目的】前立腺癌スクリーニングの効率を高める目的で、TRUSに よる前立腺体積 (PV) や移行部体積 (TZV) を用いたPSADや PSATZが検討されている。今回われわれは、前立腺癌の病期診断 に利用されているMRI画像を用いて、PSADやPSATZについて検討 した。【対象と方法】1994年1月から1999年7月までに前立腺針生検 を施行した中で、術前にMRIが撮影され、PSA值が $20 \mathrm{ng} / \mathrm{ml}$ 未満で あった前立腺癌16例（stage Bが10例、Cが6例）と肥大症24例の計 40例を対象とした。方法は、MRI画像上、等間隔で撮影された連 続横断像の面積をすべて計測し、PVとTZVを求めた。【結果】年 齢とPSA值に有意差は認められなかったが、肥大症でPVとTZVが 有意に高く、前立腺癌でPSADとPSATZが有意に高かった。そこ で、有意差を認めた4項目についてロジスティック回帰分析を施 行した結果、前立腺癌の鑑別にはPSADが有用であった。また、 ROC曲線よりPSADのcut-off值を $0.2 \mathrm{ng} / \mathrm{ml}$ とした時、感度 $81.3 \%$ 、特 異度79.2\%であった。【総括】PSA值が20 $\mathrm{ng} / \mathrm{ml}$ 未満のgray zoneにお ける前立腺癌スクリーニングにおいて、MRIによる体積推定を行 った結果、PV、TZV、PSATZよりPSADが有用と判明した。また、 そのcut-off值は $0.2 \mathrm{ng} / \mathrm{ml}$ であった。
\end{abstract}

前立腺癌 MRI PSA

\section{P-544 前立腺癌の予後因子としてのPSA $\gamma$-sm比 の臨床的検討}

\section{埼玉医科大学 泌尿器科1) \\ 朝霞台中央総合病院 ${ }^{2}$}

岩㴊 和明1) 浜田郁人 $\left.{ }^{1}\right)$ 吉野 修司 ${ }^{1)}$ 加藤 幹雄 ${ }^{1}$ 岡田 耕市 ${ }^{1)}$ 加瀬 浩史 ${ }^{2)}$

【目的】前立腺腫瘍マーカー間の検討は、前立腺特異抗原 (PSA）· $\gamma$-セミノプロテイン $(\gamma$-sm) 比が主に診断的意義にお いて検討されている。今回我々はPSA、PAP、 $\gamma$-sm、3種の腫瘍 マーカーの臨床的意義、特にその予後因子としての評価を行った ので報告する。【対象・方法】1989年1月より1998年12月までの9年 間に前立腺針生検を行い、前立腺癌と診断された139例（42-94歳、 平均 $71.8 \pm 8.2$ 歳、StageA:7例、StageB:16例、StageC:26例、StageD $: 8$ 例、StageD $\mathrm{D}_{2}$ :82例) の生検前のPSA、PAP、 $\gamma$-smについて統計学的 検討を行った。PSA、 $\gamma$-smはEIA法、PAPはRIA法を用いて測定し、 各々単独およびPSA/PAP比、PSA $/ \gamma$-sm比を中央値で2群にわけ、 生存期間の差異をKaplan-Meier法により検討した。【結果】PSA、 PAP、 $\gamma$-sm単独およびPSA/PAP比においては有意な生存への影響 を認めなかった。一方PSA $\gamma$-sm此においては、全症例拉よびhigh stage例のいずれにおいても高值群が有意に良好な結果となった。 【結語】 PSA $/ \gamma-s m$ 比は診断的意義のみならず予後因子としても有 用であることが推測された。

前立腺掂 PSA $\gamma$-sm 